\title{
Projeto de Educação Permanente com Agentes Comunitários de Saúde: relato sobre a prática extensionista de estudantes de enfermagem
}

Michelly de Souza Faria, Silas de Teixeira de Souza, Willians Guilherme dos Santos, Anna Clara Santiago Nunes Pinto, Fernanda Reis Souza, Beatriz Santana Caçador

\section{Resumo}

O Agente Comunitário de Saúde (ACS) assume lugar privilegiado para operacionalização dos princípios do Sistema Único de Saúde constituindo elo fundamental entre serviço e comunidade. Porém, evidenciam-se fragilidades na prática do ACS e na incorporação de estratégias de intervenção sustentadas pelo paradigma da promoção da saúde. Em face à necessidade de transformar esta realidade, destaca-se a importância de viabilizar espaços de reflexão sobre a prática profissional, os desafios a ela relacionados e potenciais estratégias de enfrentamento dos constrangimentos políticos e estruturais que permeiam o setor saúde no Brasil. Assim, o Projeto de Educação Permanente (PEP), constitui dispositivo potencialmente capaz de transformar o agir profissional e provocar reflexões e respostas positivas dos ACS frente aos desafios inscritos na política social de saúde. Relatar a experiência de estudantes de enfermagem sobre a participação em um Projeto de Educação Permanente com ACS, em Viçosa, MG, a partir de parceria da Universidade Federal de Viçosa e Secretaria Municipal de Saúde. Trata-se de relato de experiência de atividades extensionistas do projeto "O Agente Comunitário de Saúde: (re)construindo práticas e saberes por meio da Educação Permanente". Estruturam-se as oficinas a partir da demanda dos ACS's por formação. Utilizam-se metodologias participativas e dialógicas, privilegiando o saber dos ACS sobre sua prática profissional. O PEP é formado por estudantes de enfermagem os quais atuam voluntariamente na atividade extensionista. É coordenação por um professor que atua em conjunto com os estudantes como facilitador das oficinas, as quais acontecem mensalmente no auditório do IMAS. Realizam-se reuniões quinzenais entre os membros da equipe a fim de planejar as atividades e providenciar os materiais necessários. A integração ensino-serviço ganha concretude a partir da parceria com a prefeitura a qual viabiliza a participação dos ACS liberando-os do serviço no dia da oficina. As oficinas são divididas em três momentos: exposição dialogada, momento em que convidamos um expert sobre a temática. Em seguida, acontece a vivencia da temática seja por meio de simulação realística, estudo de caso ou outra estratégia que permita ao ACS problematizar a temática a partir de seu cotidiano. Por último, acontece a síntese do debate e esclarecimento das dúvidas. As temáticas são eleitas pelos próprios ACS e transitam entre questões da prática clínica e subjetividade no trabalho. Deste modo, as temáticas permitem aos alunos vivenciarem a construção de trabalho interdisciplinar e de construção de parcerias com diferentes serviços do município. $\mathrm{O}$ PEP cumpre com seu objetivo de promover educação permanente aos ACS ao mesmo tempo em que fortalece a integração ensino-serviço e permite aos alunos aprendizado de habilidades de liderança, trabalho em equipe e interdisciplinar.

Descritores: Enfermagem; Agentes Comunitários de Saúde; Educação Permanente 